\title{
Evaluation of the rubella surveillance system in Quebec
}

\author{
Lina Perron MD MSc ${ }^{1}$, Philippe De Wals MD PhD ${ }^{1,2}$, François Milord MD MSc FRCPC ${ }^{1,2}$
}

\begin{abstract}
L Perron, P De Wals, F Milord. Evaluation of the rubella surveillance system in Quebec. Can J Infect Dis 2000;11(6):313-316.

OBJECTIVE: To evaluate the validity of information in the rubella surveillance system in Quebec. DATA AND METHODS: Cases of rubella in the provincial registry of notifiable diseases, "Maladies à declaration obligatoire" (MADO), from 1994 to 1996 were matched with laboratory-identified cases and with cases in a reference file created from all case investigation records of regional departments of public health for the same period. Sensitivity and the proportion of cases in agreement were calculated.

RESULTS: Compared with laboratories, the sensitivity of the provincial registry was $56 \%$. Compared with the reference file, global sensitivity (confirmed cases plus clinical cases) was $58 \%$ and the positive predictive value was $50 \%$. Of the 356 cases reported to regional public health departments, $65 \%$ were classified in the same diagnostic category (confirmed case, clinical case, excluded case) by public health professionals and a group of experts (weighted kappa $=0.32$ ). Information on rubella vaccination status was missing in $25 \%$ of cases in the MADO file for rubella.

CONCLUSIONS: Notification of positive results for immunoglobulin $M$ antibodies and viral cultures should be required of all laboratories. Uniform procedures should be adopted and applied for the validation of cases that are reported to regional departments of public health. In the context of the rarefaction of rubella, any immunoglobulin M-positive result should be interpreted using all available epidemiological information.
\end{abstract}

Key Words: Laboratory; Monitoring; Rubella; Validation

\section{Évaluation du système de surveillance de la rubéole au Québec}

OBJECTIF : Évaluer la validité des données consignées dans le système de surveillance de la rubéole au Québec. DONNÉES ET MÉTHODOLOGIE : Les cas de rubéole inscrits dans le registre provincial des maladies à déclaration obligatoire (MADO) de 1994 à 1996 ont été appariés avec les cas identifiés dans les laboratoires et les cas inscrits dans un fichier de référence créé à partir de tous les dossiers d'enquête des départements régionaux de santé publique pendant la même période. On a calculé la sensibilité et le pourcentage des cas concordants.

RÉSULTATS : La sensibilité du registre provincial comparativement aux laboratoires était de $56 \%$. Comparativement au fichier de référence, la sensibilité globale (cas confirmés et cas cliniques) se chiffrait à $58 \%$, et la valeur prédictive positive, à $50 \%$. Parmi les 356 cas signalés aux départements régionaux de santé publique, $65 \%$ ont été classés dans la même catégorie diagnostique (cas confirmé, cas clinique, cas exclu) par des professionnels de la santé publique et un groupe d'experts (coefficient kappa pondéré $=0,32$ ). Les données sur la vaccination antirubéoleuse étaient manquantes dans $25 \%$ des cas dans le fichier MADO sur la rubéole.

CONCLUSIONS : On doit exiger de tous les laboratoires qu'ils signalent les résultats positifs du titrage de l'immunoglobuline $\mathrm{M}$ et des cultures virales. Une marche à suivre uniforme doit être adoptée et appliquée pour la validation de tous les cas rapportés aux départements régionaux de santé publique. Dans le contexte de la raréfaction de la rubéole, la présence de l’immunoglobuline $\mathrm{M}$ doit être interprétée à la lumière de toutes les données épidémiologiques existantes.

$\mathrm{S}$ urveillance of rubella is an integral part of efforts to eliminate this contagious, vaccine-preventable disease. In the province of Quebec, rubella cases must be reported to

public health authorities by the treating physician (1). Following receipt of a case notification and its validation, professionals of the 18 regional public health departments in

\footnotetext{
${ }^{1}$ Department of Public Health, Planning and Evaluation, Montérégie Regional Health Board, Longueuil, Quebec; ${ }^{2}$ Department of Community Health Sciences, Université de Sherbrooke, Sherbrooke, Quebec

Correspondence and reprints: Dr Lina Perron, 1255 rue Beauregard, Longueuil, Quebec J4K 2M3. Telephone 450-679-6772, fax 450-679-6443, e-mail l.perron@rrsss16.gouv.qc.ca

Received for publication July 23, 1999. Accepted November 26, 1999
} 
TABLE 1

Classification of cases in the "Maladies à declaration obligatoire" (MADO) file and in the reference file for the 356 notified cases of rubella in Quebec, 1994 to 1996

\begin{tabular}{lcccc}
\hline MADO file & $\begin{array}{c}\text { Confirmed } \\
\text { cases }\end{array}$ & $\begin{array}{c}\text { Reference file } \\
\text { Clinical } \\
\text { cases }\end{array}$ & $\begin{array}{c}\text { Excluded } \\
\text { cases }\end{array}$ & Total \\
\hline Confirmed cases & 20 & 1 & 10 & 31 \\
Clinical cases & 0 & 50 & 61 & 111 \\
Excluded cases & 0 & 52 & 162 & 214 \\
Total & 20 & 103 & 233 & 356 \\
\hline
\end{tabular}

Quebec enter the case into an electronic provincial registry of notifiable diseases, "Affichier des maladies à declaration obligatoire" (MADO). Depersonalized data from this file are available for the identification of risk factors, and analysis of geographic and temporal variations.

Objective 14 of the Politique de la Santé et du Bien-être (2) of Quebec targets elimination of rubella by the year 2002. This objective conforms to the Canadian goal of eradicating indigenous rubella infection during pregnancy by the year 2000 as defined during the Rubella and Mumps Consensus Conference (3). Eventual confirmation of elimination or near elimination of this disease requires a monitoring system that is both sensitive and specific. The present study aims to evaluate the validity of information supplied by the Quebec provincial rubella surveillance system and propose measures to improve this system.

\section{DATA AND METHODS}

Depersonalized data were obtained on rubella cases in the MADO file from 1994 to 1996, excluding congenital rubella. These cases were reported as either confirmed or clinical cases. Case definitions used in Quebec (4) during the study period conform to Canadian definitions (5). A confirmed case must fulfill one of the following conditions: in the absence of recent rubella vaccination, it must be confirmed by a laboratory test (either isolation of rubella virus, serological detection of quadrupled titre of antirubella virus antibodies or serological detection of rubella immunoglobulin [Ig] $\mathrm{M}$ antibodies); in presence of clinical manifestations that meet criteria for a clinical case of rubella, it must have an epidemiological link to a case confirmed by one of the laboratory tests mentioned above. A clinical case must meet four conditions: have clinical manifestations that do not meet the criteria for a case of measles; acute onset of a generalized maculopapular skin eruption; fever; and the presence of one of the following symptoms: joint pain or arthritis, lymphadenopathy or conjunctivitis. For each case, the information recorded was the date of disease onset, sex, birthdate, place of residence, symptoms, vaccination status and serological results.

In the province of Quebec, only four laboratories perform the test for rubella IgM antibodies. Information on positive results from 1994 to 1996 was obtained from these laboratories, but no information was available for tests with a negative result. Variables obtained included the date that the sample was taken; sex, birthdate and place of residence of the patient; se- rology of measles; and, when available, history of vaccination with the combined mumps-measles-rubella (MMR) vaccine. Cases identified by laboratories were matched to those in the MADO file to assess the sensitivity of the MADO file.

Depersonalized copies of all case investigation records for rubella cases occurring from 1994 to 1996 were obtained from the 18 provincial regional public health departments. Investigation records were unavailable for 25 cases. Using data in these investigation records, one of the researchers (LP) created a reference file by classifying cases into three categories (confirmed case, clinical case, excluded case) using the criteria mentioned above. A positive response to the three questions about skin eruption, fever and the presence of other symptoms was necessary for the case to be classified as a clinical case, even if there was no other information about these symptoms (for example, the maculopapular nature of the eruption). Regarding vaccination status, the person was considered vaccinated if he or she had received a dose of antirubella vaccine with the vaccination date present in the medical file. In the absence of the date of vaccination, the person was considered nonvaccinated. If the person did not know his or her vaccination status, the response was considered unknown. When no response was present, information was considered missing. Cases in the reference file were matched to to those in the MADo file to calculate the proportion of cases in agreement.

\section{RESULTS}

For the years of 1994, 1995 and 1996, 63 cases, 48 cases and 56 cases of rubella, respectively, were recorded in the MADO file. This gave a total of 167 cases, $22 \%$ confirmed and $78 \%$ clinical. Information on vaccination status was missing in $25 \%$ of cases in the MADO file, $31 \%$ of clinical cases and in $8 \%$ of confirmed cases. The vaccination status was known for 35 confirmed cases and 90 clinical cases: $47.2 \%$ vaccinated, $36 \%$ nonvaccinated and $16.8 \%$ unknown. The percentage of confirmed patients who were vaccinated was $37.1 \%$.

A total of 38 positive serology tests for rubella IgM antibodies were identified by the laboratories. Only half of these cases (19 of 38) were known to their regional public health departments. Excluding four persons who had received the MMR vaccine in the 56 days (eight weeks) before samples were taken, sensitivity of the MADO file for laboratory-confirmed cases was $56 \%$ (19 of 34$)$.

The reference file contained 356 cases, 20 of which were classified as confirmed cases, 103 as clinical cases and 233 cases were excluded (Table 1). Compared with the reference file, overall sensitivity of the MADO file (confirmed cases plus clinical cases) was $58 \%$ (71 of 123 ) and the overall positive predictive value was $50 \%$ (71 of 142). Of the 356 cases reported to regional public health departments, $65 \%$ were classified in the same diagnostic category (confirmed case, clinical case, excluded case) in public health case investigation records and in the reference file (weighted kappa value $=0.32$ ). The main source of disagreement was the records of 11 confirmed and 61 clinical cases in the MADO file for which criteria of the case definition of rubella had not been met.

When the epidemiological indicators calculated from the 


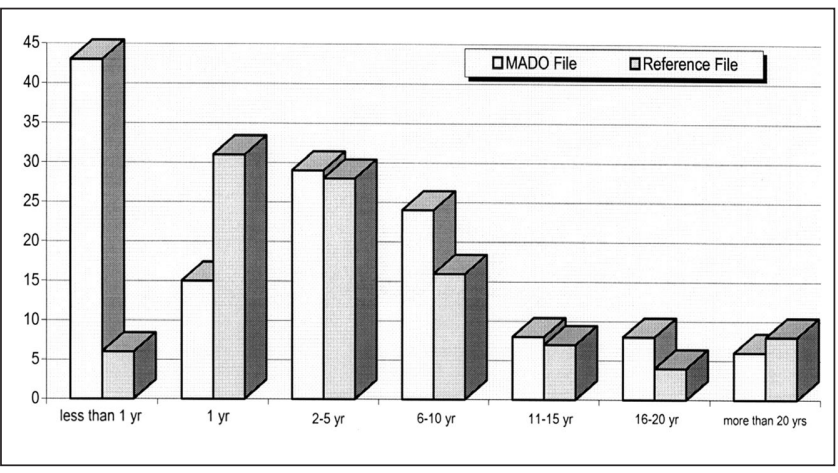

Figure 1) Distribution of confirmed cases of rubella by age groups at disease onset, Quebec, 1994 to 1996

MADO file were compared with those calculated from the reference file, many differences were observed. Annual average incidences of rubella calculated were $0.8 / 100,000$ versus $0.6 / 100,000$, respectively. The masculine proportion of cases was $51.5 \%$ for the MADO file versus $49.2 \%$ for the reference file. Distributions of confirmed cases and clinical cases by age groups for the two files are presented in Figures 1 and 2 . The MADO file contained a large number of clinical cases in infants younger than one year of age; these cases were not validated by an expert. Thus, there are appreciable differences in specific incidence rates by diagnostic category and age group.

\section{DISCUSSION}

The present study has shown the lack of validity of the Quebec provincial rubella monitoring system. These conclusions are analogous to results previously reported from other areas $(6,7)$. A study in the state of Vermont, where notification of rubella is the responsibility of physicians, indicates that a maximum of $64 \%$ of notifiable diseases were actually reported (6). In Quebec, where notification of cases of rubella identified by laboratories is left to the laboratory's discretion, sensitivity of the provincial MADO file compared with cases identified by laboratories was $56 \%$. Certain cases were known to Quebec regional public health boards because they had asked for laboratory tests for rubella IgM antibodies. We would expect the proportion of cases diagnosed by laboratories following requests from clinicians and then reported to public health departments to be lower. To increase the sensitivity of the surveillance system, rubella declaration by laboratories should become a legal obligation, adding it to the list of notifiable diseases. Results of the present study illustrate the many problems in obtaining a valid case list for rubella. Differences in disease incidence and age distribution of cases were observed when the same data set was analyzed by health professionals from regional public health departments and experts. The clinical diagnosis of rubella was unreliable, and the notion of clinical case as recommended in the Rubella Consensus Conference (3) should be abandoned. In Finland, in a context of the rarity of measles, rubella and mumps, the positive predictive value of a clinical diagnosis was only $4 \%$ (7).

When the diagnosis of rubella is suspected, laboratory tests should be performed. Viral culture is a specific method,

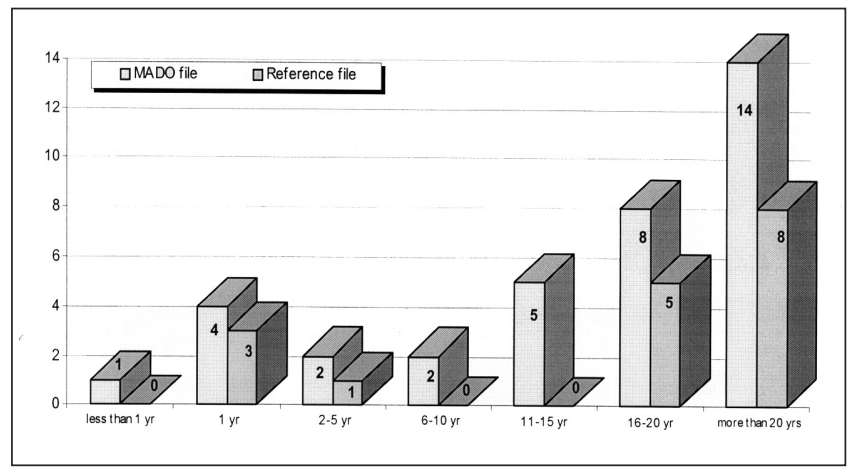

Figure 2) Distribution of clinical cases of rubella by age groups at disease onset, Quebec, 1994 to 1996

and a significant rise in specific rubella antibodies provides good evidence of infection. The interpretation of a single IgMpositive result is always difficult, and data are not available to provide precise guidelines. In the Canadian situation, the probability of a false positive IgM result is high in the absence of an epidemiological link to another confirmed case. Following vaccination, as in primary infection, the persistence of IgM is variable and may be very long in a few individuals (8). The measure of avidity of antibodies can be a means in distinguishing between old and recent infections, but it is rarely done in practice (9). Cross-reactions can also occur after recent infections with other viruses, such as the Epstein Barr virus and the cytomegalovirus (8).

To assure that the best possible quality (accuracy, completeness and uniformity) of information is recorded in the surveillance system, the use of a standard case investigation questionnaire is recommended. For all confirmed cases of rubella, the following information should be available: date of disease onset; origin (indigenous or imported); age, sex and place of residence; vaccination status (and when applicable, if two doses of vaccine were received); history of travel; contacts with travellers or sick people; and results of laboratory tests. The final decision to register a rubella case requires a sound medical interpretation combining clinical, epidemiological and laboratory information.

Our study has certain limitations, including the fact that important details may have been missed by the researcher during case classification. It is possible that findings (such as the presence of a specific symptom) were not noted by public health professionals in their case investigation records. This limitation implies that the real proportion of cases in agreement may actually be higher than that indicated in this study.Finally, given that no epidemics of rubella occurred in Quebec during the study period, the conclusions of this study do not apply during an epidemic period of rubella.

The question of the validity, and ultimately the utility, of a monitoring system is crucial for the surveillance of all diseases, especially those on the way to elimination such as rubella, measles and mumps. In 1994,Klaucke (10) noted that: "Determining the most efficient approach to monitoring for a given health event is an art. There is room for creativity and the opportunity to combine scientific rigor with practical realities." 
ACKNOWLEGDEMENTS: Grant support received from Ministère de la Santé et des Services sociaux du Québec, Québec.

\section{REFERENCES}

1. Québec (Province), Assemblée nationale. Règlement d'application de la Loi sur la protection de la santé publique. LRQ, chapitre P-35, $\mathrm{r}$.

2. Ministère de la Santé et des Services sociaux. La politique de la santé et du bien-être. Québec: Gouvernement du Québec, 1992:100.

3. Mumps and Rubella Consensus Conference. Can Commun Dis Rep 1994;20:165-76.

4. Direction générale de la santé publique. Surveillance des maladies infectieuses à déclaration obligatoire au Québec. Définitions nosologiques. Québec: Ministère de la santé et des services sociaux, 1991:19.
5. Bureau of Communicable Disease Epidemiology. Cases Definitions and Specific Surveillance Methods for each Disease. Can Commun Dis Rep 1991;17S-3:23.

6. Vogt RL, La Rue D, Klaucke DN, Jillson DA. Comparison of an active and passive surveillance system of primary care providers for hepatitis, measles, rubella, and salmonellosis in Vermont. Am J Public Health 1983;73:795-7.

7. Peltola $\mathrm{H}$, Heinonen OP, Valle $\mathrm{M}$, et al. The elimination of indigenous measles, mumps, and rubella from Finland by a 12year, two dose vaccination program. N Engl J Med 1994;331:1397-402.

8 Cradock-Watson JE. Laboratory diagnosis of rubella: past, present and future. Epidemiol Infect 1991;107:1-15.

9. Helman K, Rousseau SA. Measurement of avidity of specific IgG for verification of recent primary rubella. J Med Virol 1989;27:288-92.

10. Klaucke DN. Evaluating public health surveillance. In: Teutsch SM, Churchill RE, eds. Principles and Practice of Public Health Surveillance. New York: Oxford University Press, 1994:159. 


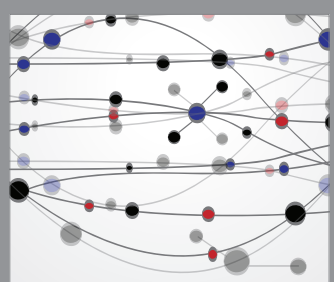

The Scientific World Journal
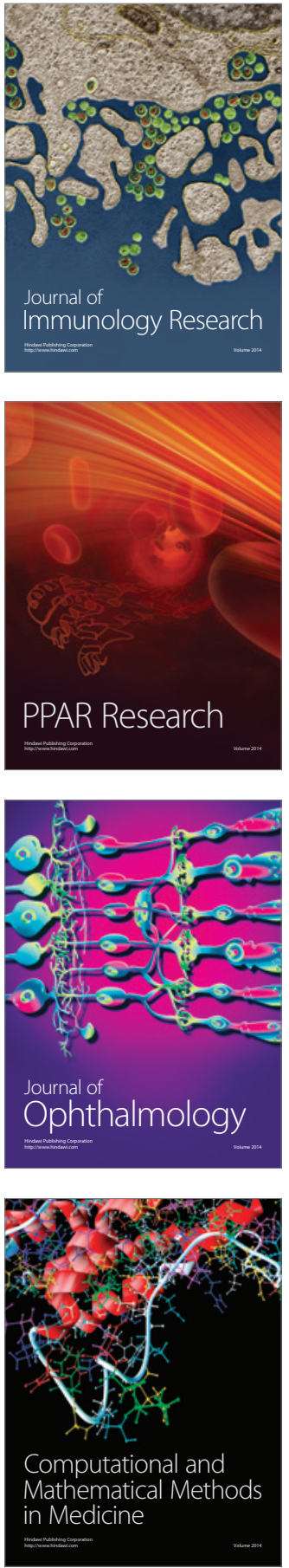

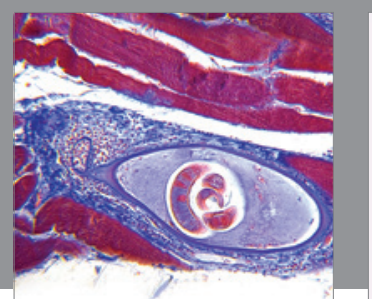

Gastroenterology Research and Practice

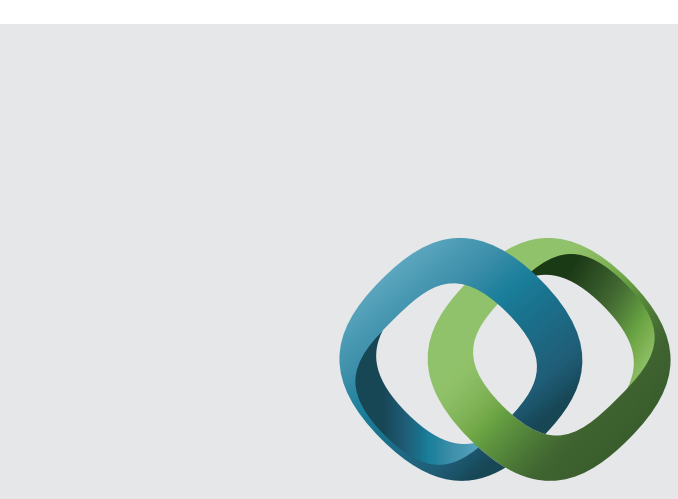

\section{Hindawi}

Submit your manuscripts at

http://www.hindawi.com
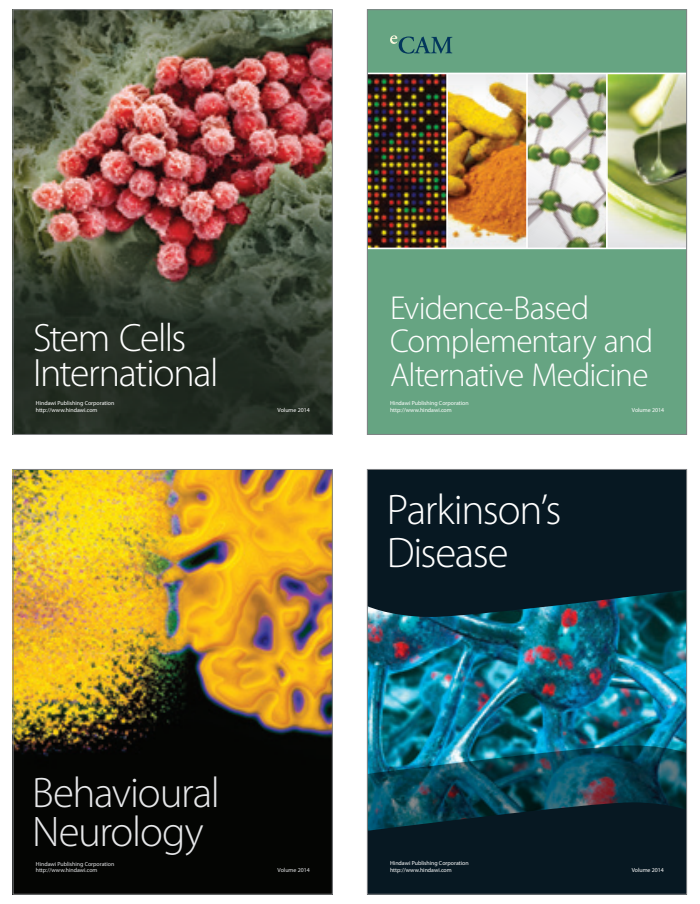
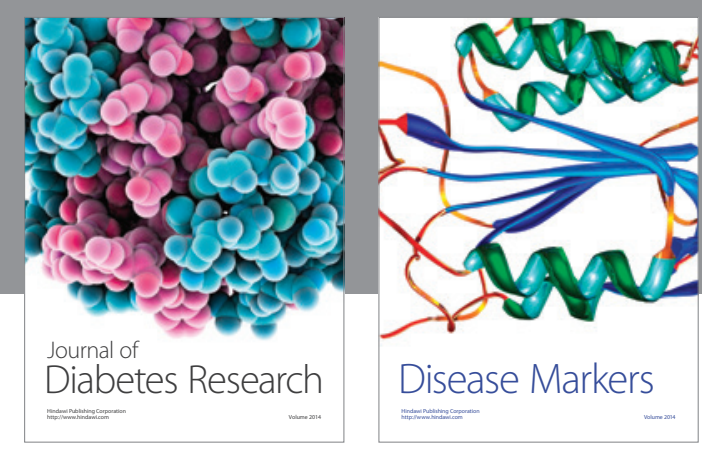

Disease Markers
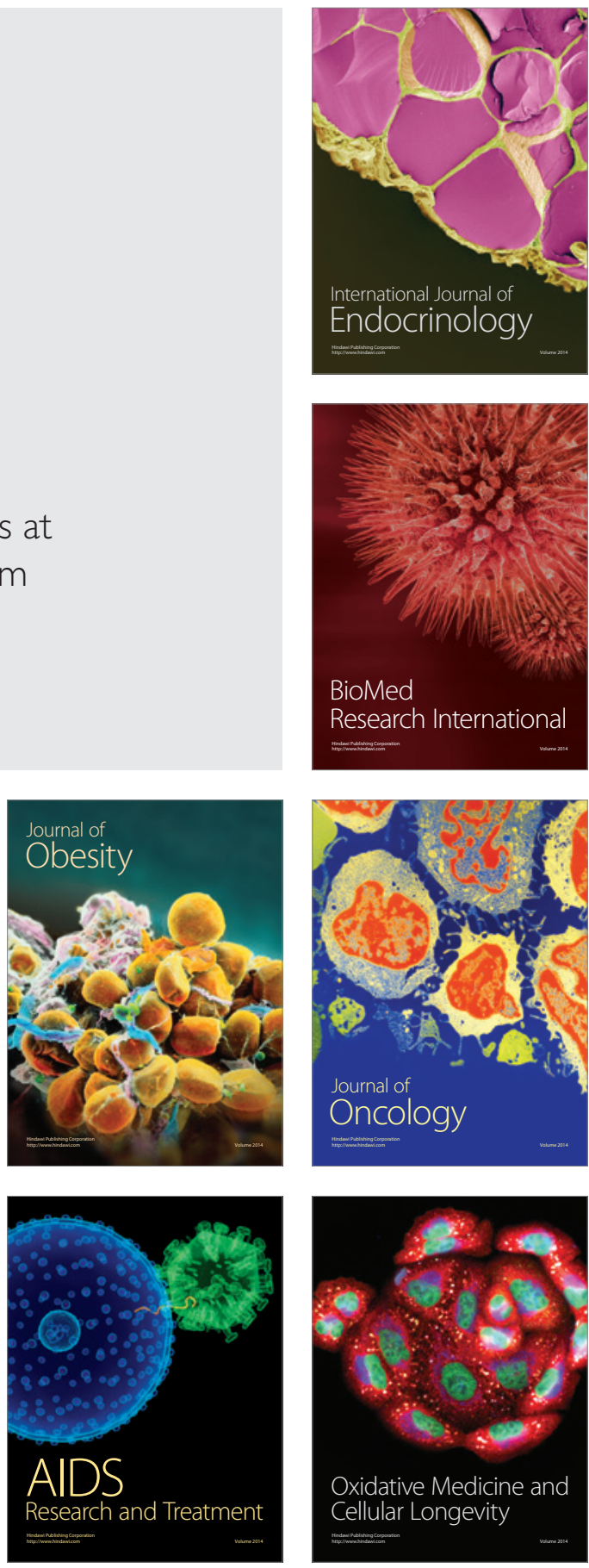